\title{
Technology and Innovation Management
}

\section{Working Paper/Arbeitspapier}

\section{Customer on the Move:}

Strategic Implications of Mobile Banking for Banks and Financial Enterprises

\author{
Rajnish Tiwari \\ Stephan Buse \\ Cornelius Herstatt
}

February 2006

Working Paper No. 38

This paper was presented at the 8th IEEE International Conference on

E-Commerce Technology, 26 - 29 June 2006, San Francisco

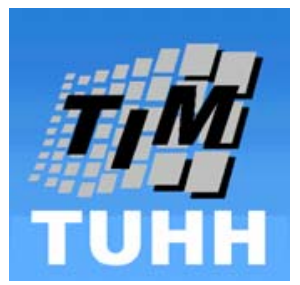

Hamburg University of Technology (TUHH)

Institute of Technology \& Innovation Management

Schwarzenbergstr. 95, D-21073 Hamburg-Harburg

Tel.: +49 (0)40 42878-3777; Fax: +49 (0)40 42878-2867

www.tu-harburg.de/tim 


\title{
Customer on the Move: Strategic Implications of Mobile Banking for Banks and Financial Enterprises
}

\author{
By Rajnish Tiwari, Stephan Buse, and Cornelius Herstatt \\ Hamburg University of Technology \\ Institute of Technology and Innovation Management \\ Schwarzenbergstrasse 95, 21073 Hamburg, Germany \\ Tel: +49-40-42878-3776, Fax: +49-40-42878-2867 \\ www.tuhh.de/tim \\ rajnish.tiwari@tuhhh.de,stephan.buse@tuhh.de,c.herstatt@tuhh.de
}

\begin{abstract}
The increased need/wish for mobility amongst various sections of the society, particularly amongst professionally active groups, is confronting credit institutions (banks) and other enterprises offering financial services, with challenges to adjust their service portfolio in a way to best suit the needs of their customers. On the other hand it also opens up a new arena of opportunities by making it possible to offer innovative, value-added services so as to not only cater to the needs arising out of the mobility but also by actively inducing demand for new, mobility-centric services.

This paper examines strategic implications of these changes in customer behavior as perceived by the banks. It introduces the findings of a bank survey conducted by the authors in Germany. The survey discovered that banks expect Mobile Banking to gain greater relevance in near future and are positioning themselves not to be left behind.
\end{abstract}

Keywords: Mobile Banking, Mobile Financial Services, Mobile Commerce, Mobile Business, Multi-channel strategy

Published in: “E-Commerce Technology 2006” (CEC/EEE 06), ISBN: 0-7695-2511-3.

\section{This paper should be referred to as following:}

Tiwari, R., S. Buse, and C. Herstatt (2006): “Customer on the Move: Strategic Implications of Mobile Banking for Banks and Financial Enterprises”, in: CEC/EEE 2006 - Joint

Proceedings of the 8th IEEE International Conference on E-Commerce Technology, and the 3rd IEEE International Conference on Enterprise Computing, E-Commerce, and E-Services, (CEC/EEE'06), San Francisco, pp. 522-529. 


\section{Introduction}

Mobile Banking, the placement as well as availment of financial services via mobile devices such as cell phones, has staged a remarkable come-back. After nearly four years of oblivion in the aftermath of the dotcom-crash it is gaining increasing customer acceptance.

Impressive growth can be observed in the offers and usage of Mobile Banking worldwide (see e.g. [6, 8, 12, 18, 22, 23]). The growth in some regions may even be characterized as exceptional. For instance, the number of financial transactions carried using mobile devices in South Korea "rose to 287,000 on a daily average, up 104.4 percent from a year earlier, according to the Bank of Korea”, where as the number of customers registered for mobile services grew to 1.9 million registering an increase of over $108 \%$ in the same period [13]. In a study conducted by the authors of this paper, up to $92 \%$ of survey participants in Germany showed their willingness to avail certain mobile financial services. Up to 74\% were willing to pay for these services. Since mobile telephony is getting cheaper on account of increased competition [20], this trend may be expected to grow further.

These developments point towards an increasingly positive perception of mobile financial services in the society. This shift in perception can be traced back to mainly following factors:

i) The penetration of the society by mobile phones has reached an all-time high, e.g. nearly $87 \%$ of all German residents and over $79 \%$ of all South Koreans reportedly possess a mobile phone [5, 22].

ii) The integration of world economies is leading to more mobility so that availment of mobile services is no more a luxury but a necessity for many.

iii) The younger generations of the society seem to be fascinated by modern data and telecommunication services.

iv) Mobile devices have become more powerful. Data transmission has become faster with the launch of new standards, such as the Universal Mobile Telecommunications System (UMTS).

The above-mentioned factors have led to an increased demand in services that can be offered and availed via portable mobile devices enabling ubiquitous (“anytime, anywhere”) access to services including to those of a financial nature.

Banks and other financial enterprises (hereafter jointly referred to as banks) are thus confronted with a challenge to cater to these needs [11]. On the other hand, this situation also opens up a new arena of opportunities for banks by making it possible to offer innovative, 
value-added services that are mobility-centric, e.g by offering not only "anytime, anywhere" access to bank accounts but also by providing context-specific, location-based services related to banks. An example of such services could be the mobile-aided search for the nearest Automatic Teller Machine (ATM) in an unfamiliar city.

This paper sets out to examine the implications of these developments for the banking sector. For this purpose it first defines the phenomenon of Mobile Banking and describes various services that are conceivable. An analytical framework of the utility of mobile services is provided in chapter 3. Chapter 4 introduces briefly the results of a survey of prospective customers, the 5th chapter those of a bank survey. Both of these surveys were carried out by the authors as part of a research project to investigate the prospects of Mobile Commerce in Germany in various branches. The 6th chapter entails a strategic assessment of the survey results. Chapter 7 contains final conclusions and outlook.

\section{Definition and Scope Issues}

Finance-related services that are offered by employing mobile telecommunication technologies are generally referred to as "Mobile Financial Services" (MFS). They can be divided into two categories: "Mobile Payment" and "Mobile Banking" [7]. Since Mobile Payment constitutes an independent business field [7, 21], it is not taken into further consideration here. The term MFS, in this paper, hereafter refers to MFS in the banking sector (Mobile Banking). The term “Mobile Banking” may be defined as following:

"Mobile Banking refers to provision and availment of banking and financial services with the help of mobile telecommunication devices. The scope of offered services may include facilities to conduct bank and stock market transactions, to administer accounts and to access customized information.” [21]

Mobile Banking covers a wide spectrum of banking-related services. The offered services can be categorized as following [7]; (for a thorough discussion of these issues see: [21]):

i) Mobile Accounting: Mobile Accounting refers to utilization of banking services of non-informational nature that are specific to a particular account, via mobile telecommunication devices. The offered services may include remittance facilities, access administration and card management.

ii) Mobile Brokerage: Mobile Brokerage refers to transaction-based, mobile financial services of non-informational nature revolving around a securities account. The scope of offered services may include selling \& purchasing of financial instruments 
(e.g. stocks, bonds or derivatives), order book administration and access administration.

iii) Mobile Financial Information Services: These services refers to banking- and financial services that are non-transaction based and therefore of purely informational nature. The information may relate to either own bank account(s) or to market developments. A bank may offer Mobile Financial Information services as an independent module, i.e. without offering Mobile Accounting or Mobile Brokerage services; but vice versa (i.e. accounting or brokerage services without offering information services) is not feasible. The scope of offered services may include, but is not limited to, facilities to make balance enquiries, order statements of account, issue threshold-alerts for transaction-limits, for balance-levels or for stock prices, receive confirmation on completion of placed orders and to receive or order up-to-date information on market developments (on both pull and push basis).

\section{Utility of Mobile Financial Services}

In the following we describe potential advantages of mobile financial services from the respective perspectives of bank customers and banks.

\subsection{The customer perspective}

Mobile Banking is characterized by some unique features that equip it with certain advantages against conventional forms of banking [1, 3, 10, 15]:

i) Ubiquity: The user can avail of services and carry out transactions largely independent of his current geographic location (“anywhere” feature).

ii) Immediacy: The possibility of real-time availment of services ("anytime” feature) is particularly attractive for services that are time-critical and demand a fast reaction, e.g. stock market information for a broker.

iii) Localization: Positioning technologies can be used to offer location-based services to meet customers' needs e.g. to search for an ATM or a bank-branch.

iv) Instant connectivity: Mobile devices are constantly "online”, i.e. in touch with the network (“always-on” feature). So that time-consuming dial-up or boot processes are not necessary.

v) Pro-active functionality: The customer may choose to receive information on pull and/or push basis, thereby deciding the content and frequency of messages. 
vi) Simple authentication procedure: Mobile telecommunication devices function with an electronic chip called Subscriber Identity Module (SIM). The SIM is registered with the network operator and the owner is, in combination with an individual Personal Identification Number (PIN), unambiguously identifiable.

The above mentioned features of Mobile Banking make it particularly suitable for timecritical situations. Additionally, they are useful for catering to spontaneous decisions and needs, which do not require a very careful decision. It may also help increase efficiency for example by contributing to better utilization of time spent during travels [2].

\subsection{The banks’ perspective}

Including MFS in portfolio may be an attractive proposition for a bank for following reasons:

i) Adapting to the needs of core customer groups: Banks, today, are increasingly confronted with technology-savvy customers who are often on the move and "want to organize banking transactions while on the move, irrespective of opening hours” [17]. Banks are responding to this change by introducing mobile services. Moreover banks wish to cultivate younger generations, the prospective customers of tomorrow.

ii) Mobile Banking as distribution channel: Mobile Banking enhances the number of existing distribution channels that a bank employs. It may thus contribute to the business by increasing sales volume, e.g. by inducing demand. For instance, selling/purchasing of stocks on an urgent basis could be triggered in case of unusual market developments with the help of "push" services. It can also be employed to reduce distributions costs and increase customer satisfaction [14].

iii) Mobile Banking as a source of revenue: Mobile Banking can also serve as a source of revenue. Innovative, mobility-centric services can be offered on a premium basis. This would not only help generate additional revenues from the existing customer-base but may even attract new customers. The example of France’s Société Générale is a proof for this: Its premium service of SMS-alerts called "Messalia” was subscribed by over 640.000 customers at the year-end 2004 [19] and had managed to generate profits ever since its inception in 2001 [9].

iv) Mobile Banking as an image-enhancing product: Finally, Mobile Banking can be used as an image-enhancing product to gain strategic advantages. The bank may hope to win or retain a positive image amongst technology-savvy sections of the 
society and strengthen the brand-reputation of being innovative and visionary [7]. Further, the bank can profit from an early-mover advantage by actively shaping technological standards based on one’s own strengths.

The next section briefly describes some finding of a customer survey carried out by the authors in Germany (for detailed information see [21]).

\section{Results of a Customer Survey}

A customer survey was carried out in June/July 2005. A total number of 452 valid samples were collected in German cities of Hamburg, Frankfurt and Munich. Survey participants were in the age-group of 18 to 65 years. Investigated issues included customer perception of Mobile Banking, utility of 17 different services and the willingness to pay for them. The charts below show the ratings received by the services "Mobile Remittance" and "Balance Enquiries” via mobile devices [21] and demonstrate the large-scale positive perception of Mobile Banking that in the meanwhile seems to prevail in the society.

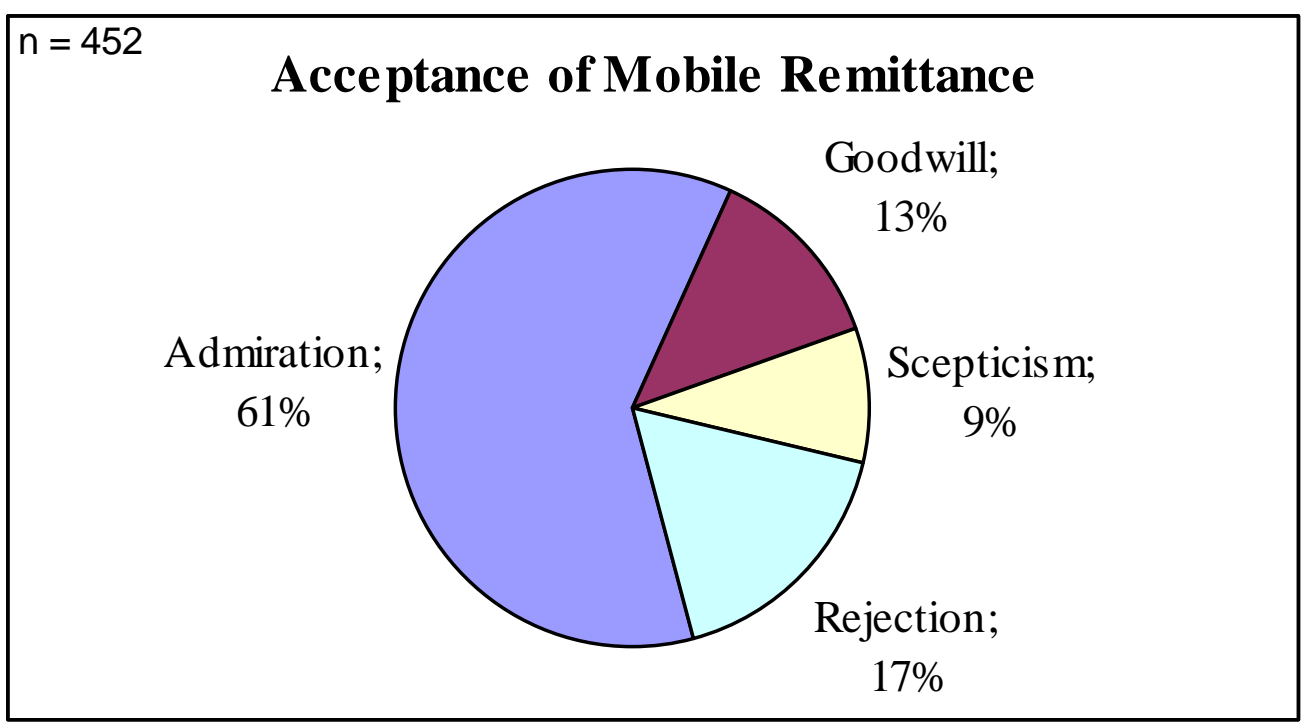

Figure 1: Acceptance of Mobile Remittance 


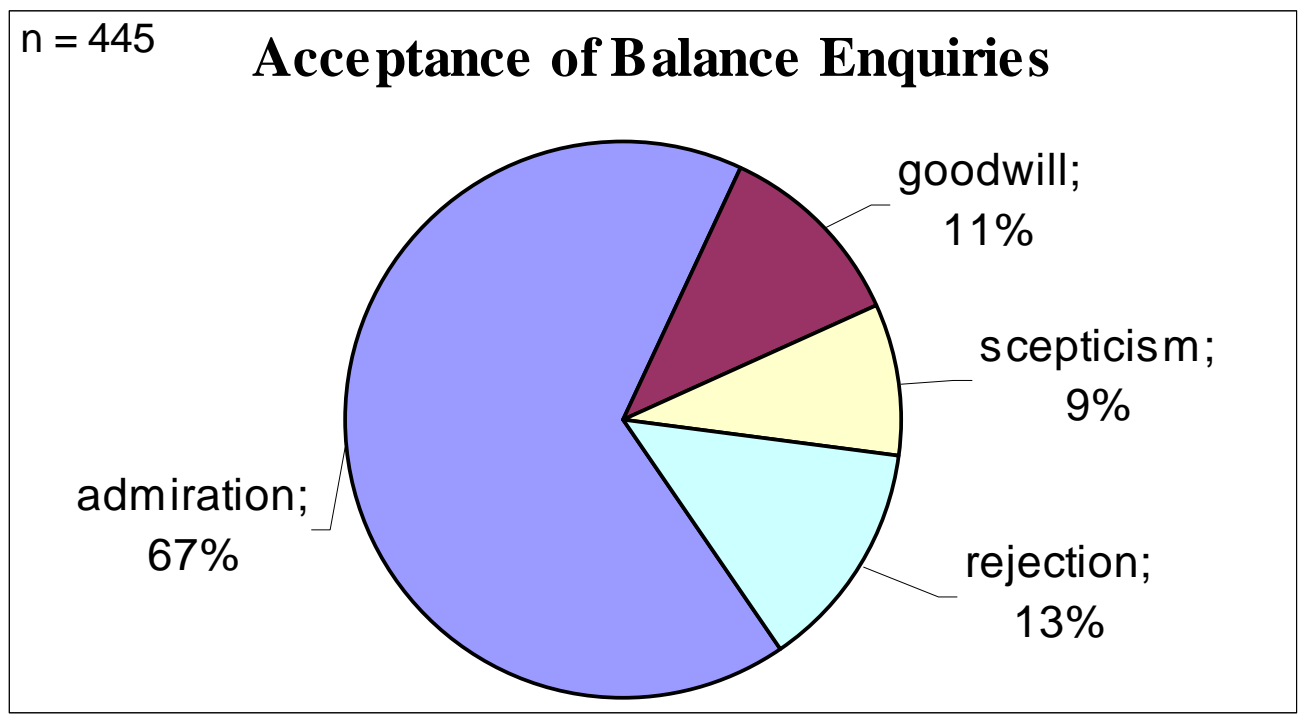

Figure 2: Acceptance of balance enquiries

Familiarity with Mobile Banking: 12\% of all survey participants (55 of 452) reported to have used MFS, at least once. $42 \%$ amongst them stated to be regular users; another $36 \%$ used Mobile Banking occasionally. Existing users belonged mostly to the groups of top management, self-employed or the salaried class; 75\% made use of Online Banking.

Willingness to pay: All in all, 335 of the 452 participants (74\%) agreed to pay for the utilization of certain, but not all, mobile services.

Features of Mobile Banking: The "anytime, anywhere” feature of Mobile Banking was the reason most often cited for, and security concerns against, the use of MFS. Mobile Remittance and Card Management were services most asked for in the field of Mobile Accounting. The popularity of Mobile Brokerage was limited to certain sections. Balance Enquiries and Branches/ATM Finders were services most asked for in the field of Mobile Financial Information.

Real Rate of Rejection (RRR): 34 of the 452 participants (8\%) rejected the usage of all 17 services categorically. The RRR is therefore surprisingly low.

\section{Banks’ Perception of Mobile Banking}

A bank survey was conducted to understand factors that might be influencing decisions of banks in Germany (and German-speaking parts of Switzerland) regarding, whether or not to offer mobile financial services, the exact scope of such services, the mediums to employ, customer groups to target and the objectives to pursue. In the following, we present selected findings of the survey (for details see [21]). 


\subsection{Methodology \& Composition of the Survey}

The survey was conducted in August/September 2005. 26 banks from Germany and 2 Swiss banks that were identified during literature review as offering or having ever offered MFS were contacted for their views. A 5-page questionnaire was prepared for the purpose of this survey. 16 banks agreed to participate. All interview partners belonged to senior management and enjoyed decision-making powers in the area of Mobile Banking in their respective institutions.

Structure: The participant banks were, as first, requested to provide some general information about their domestic business, e.g. the bank-group, the number of their retail/private customers, the usage of online- and Home Banking and their current position on Mobile Banking. The participants were then requested to identify their objectives in offering mobile financial services and to evaluate the importance of these objectives for their respective institutions on a scale of 1 ("very high significance") to 6 ("without any significance"). Participants that did not offer MFS were asked to evaluate inhibition factors on a scale of 1 ("very significant hindrance") to 6 ("no hindrance at all”). The same scale of 1 ("I agree completely") to 6 ("I disagree completely") was used again to test the responses to some general theses concerning Mobile Banking. This final question was to be answered by all banks, irrespective of the presence or absence of Mobile Banking in their product portfolio.

Scale: An even and broad scale of 1 to 6 was selected deliberately to generate precise responses on the one hand and to deny participants the easy option of a "golden middle" on the other. Further, the scales were labeled with explicit tags to avoid subjective scaling by participants and ensure consistency in answers.

It is to be noted that any percentile data presented here must be considered with certain reservations, as the sample base (16) is too low to guarantee statistical significance. Nonetheless, the results here imply opinions of some of the leading banks in Germany and Switzerland. The results, at the very least, provide an insight into banks' perception about Mobile Banking from this region. All percentage figures have been rounded up or down to the nearest round figure. This may cause, in some cases, apparent discrepancies that the figures do not add up to exactly 100.

Composition of survey participants: The 16 banks that participated in this survey represented a wide-spectrum of the German banking sector. Of 5 German big banks 4 
participated in this survey with the only exception of Commerzbank. Figure 3 gives an overview of the survey composition:

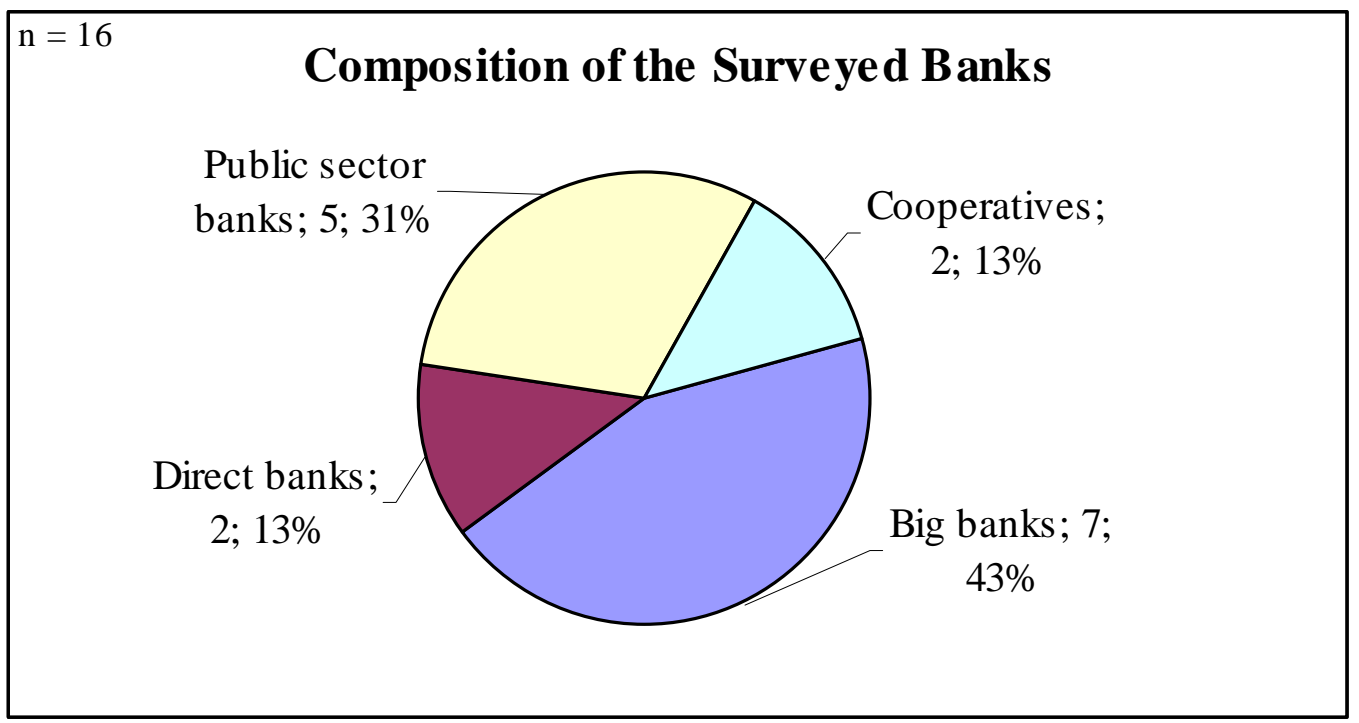

Figure 3: Composition of the surveyed banks

Eight of the surveyed banks could boast of up to five million retail customers. Two banks had a retail customer base of over five million. The smallest banks had a retail customer base of between one hundred thousand and half a million. All banks offered Online Banking. The percentage of retail customers using Online Banking ranged between 10\% and 97\%. The number of online customers was, not surprisingly, particularly high amongst the customers of direct banks and those specializing in online services.

\subsection{Selected Findings of the Survey}

In the following we present some selected findings of the bank survey.

Mobile Banking offers: 12 of the 16 surveyed banks were already offering MFS, even when the scope of the offered services differed considerably. One bank planned to (re-)launch MFS in 2006. 3 banks did not have any plans as of now to launch Mobile Banking. Two of them, however, expected Mobile Banking to establish itself in the long run but did not wish to take a pioneer role themselves. One small-sized bank offering a limited scope of mobile services referred to its offer as an "alibi offer”, meant for customers who proactively enquired about it. That bank did not see any significant relevance for Mobile Banking in its house, owing to what it termed was its "unique” customer structure. 
Futuristic planning: All banks that agreed to go on record about the number of their Mobile Banking users stated this number to be less than $1 \%$ of all retail customers. One bank reported the number of its customers utilizing SMS alert service to be $5 \%$. This fact signifies that Mobile Banking does not play any significant role in the banking business as yet. Mobile Banking remains, as of now, a niche product and banks are currently positioning themselves in this field, apparently, with an eye on the future.

Free-of-charges services: The perception of positioning for the future was enforced by the fact that most banks offered mobile services for either completely or nearly free-of-charge. Only two banks reported nominal monthly fees of $€ 1.50$ and $€ 1.00$ respectively for receiving SMS alerts. One bank reported in-principle plans to charge fee for service utilization. Another bank planned to charge its Mobile Banking customers a fee of $€ 0.20$ per transaction.

Objectives pursued by Mobile Banking offers: Banks offering MFS were asked about the objectives that they might have been pursuing with these offers. Nine possible objectives were presented to the participants with a request to evaluate their possible influence, on a scale of 1 ("very high influence") to 6 ("no influence at all”). The table below shows average ratings in ascending order received by individual objectives; the nearer a rating is to 1 , the higher the influence and vice versa.

Table 1: Mobile Banking objectives

\begin{tabular}{|c|l|c|}
\hline No. & \multicolumn{1}{|c|}{ Objective } & Ranking \\
\hline 1 & Fostering innovative image & 1.67 \\
\hline 2 & Better customer relations management & 1.92 \\
\hline 3 & Differentiation vis-à-vis rivals & 2.75 \\
\hline 4 & Attracting new customers & 3.17 \\
\hline 5 & Increase in the turn-over & 3.58 \\
\hline 6 & Increased workflow-efficiency & 3.83 \\
\hline 7 & Cost reduction & 4.00 \\
\hline 8 & Higher flexibility in business processes & 4.00 \\
\hline 9 & Increased motivation of the workforce & 4.33 \\
\hline
\end{tabular}

Two participants emphasized the importance of multi-channel approach. The average ratings reveal that banks are often motivated by "soft" strategic reasons while offering MFS and deciding their scope, than by "hard” business reasons. 
Target customer groups: Banks offering mobile services were asked about customer segments that they sought to target with their mobile services. Most banks (75\%) believed that those with high technological affinity were most likely to use mobile services. Financially affluent sections of the society were also regarded as attractive groups. Students and executives belonging to top management received similar attention (both 42\%). The salaried class (25\%) was not thought to be very attractive. Other groups cited as attractive for Mobile Banking services were: users of Online Banking; employees on the move (e.g. sales representatives); young people; active stock market traders; the self-employed; and small enterprises. One participant considered every user of mobile phone to be a prospective MFS customer, once the prices of better mobile devices became payable for everyone.

Arguments against Mobile Banking: Banks that neither offered nor planned to offer MFS in near future were asked about reasons for their decision. These banks had offered MFS previously. Participants were requested to specify their reasons for the discontinuation. Participants could evaluate possible inhibiting influence of several factors on a scale of 1 ("very significant hindrance”) to 6 ("no hindrance at all”). They could, additionally, name other hindrances that might have played a role. The table below shows average ratings received by individual factors in ascending order; the nearer the rating is to 1 , the higher is the hindering influence and vice versa.

Table 2: Arguments against Mobile Banking

\begin{tabular}{|c|l|c|}
\hline No. & \multicolumn{1}{|c|}{ Possible hindrance } & Ranking \\
\hline 1 & General lack of customer demand & 1,50 \\
\hline 2 & Insignificant for “our” customers & 2,75 \\
\hline 3 & Prohibitive costs of operation & 3,00 \\
\hline 4 & Bank products are not suitable for mobile mediums & 3,50 \\
\hline 5 & Compatibility problems with existing IT infrastructure & 3,75 \\
\hline 6 & Security concerns & 5,25 \\
\hline 7 & Lack of internal expertise & 5,25 \\
\hline 8 & Disinterest of top management & 5,75 \\
\hline 9 & Collision with other distribution channels & 5,75 \\
\hline
\end{tabular}

Table 2 suggests that banks which decided against Mobile Banking did so owing to "bad" experiences that they made in the aftermath of the dotcom burst. The primary motivation for their decision has been the lack of customer demand. High costs also seem to have played a 
certain role, even when not the crucial one. Compatibility problems with the existing IT infrastructure, the need for internal expertise or security concerns do not seem to have played a key role in the decision against Mobile Banking. All respondents assured that disinterest on the part of top management was not a factor. Importantly, none of the respondents saw any serious conflict between Mobile Banking and other classic channels of distribution. One participant mentioned lack of established standards (at that point of time) which led to many problems; for his institution could not cope with "hundreds of different models of mobile phones, all differing not only in the look and size but also in technological features”.

Theses about Mobile Banking: All participants, irrespective of the status of their offers on mobile financial services, were confronted with 9 thought-provoking theses regarding Mobile Banking. The theses were to be evaluated on a scale of 1 ("I agree completely") to 6 ("I disagree completely"). Higher ratings do not necessarily mean negative evaluation of Mobile Banking. The ratings are shown in the table below in ascending order.

Table 3: Evaluation of Mobile Banking Theses

\begin{tabular}{|c|l|c|}
\hline No. & \multicolumn{1}{|c|}{ Thesis: Mobile Banking... } & Ranking \\
\hline 1 & provides additional value vis-à-vis Online Banking! & 2.67 \\
\hline 2 & helps banks to differentiate vis-à-vis rivals! & 2.67 \\
\hline 3 & is just a new distribution channel! & 2.73 \\
\hline 4 & requires firms to forge alliances and cooperate! & 3.00 \\
\hline 5 & activities of rivals force banks to develop own strategies in this field! & 3.20 \\
\hline 6 & will increase the degree of rivalry amongst banks! & 3.40 \\
\hline 7 & will increase the threat of entry by external players! & 3.60 \\
\hline 8 & will adversely affect the no. of branches \& employees! & 4.80 \\
\hline 9 & is nothing but a short-term fashion! & 5.27 \\
\hline
\end{tabular}

Mobile Banking is thus thought to provide additional value vis-à-vis Online Banking. Moreover, the ratings suggest that banks see a moderate potential in MFS to differentiate themselves vis-à-vis rivals. At the same time, they regard Mobile Banking as nothing more than a new, additional distribution channel. Banks do not see any noteworthy, negative impact of Mobile Banking on the number of branches or employees. And, perhaps most important of all, banks do not regard Mobile Banking as a short-term fashion. That means most banks are convinced that Mobile Banking is here to stay. 
In fact, $50 \%$ of all respondents (8 out of 16) rejected the thesis "Mobile Banking is nothing but a short-term fashion” with a rating of 6 ("I disagree completely”). Even 2 of the 3 banks that did not offer Mobile Banking disagreed with this notion. This evaluation shows that banks have accepted Mobile Banking as an integral part of modern banking. The only question for some of them is of "when" and no more of "whether" to offer mobile financial services.

\section{Strategic Assessment}

The survey results demonstrated unambiguously that Mobile Banking has staged a remarkable comeback. Banks are seeing themselves increasingly forced to include mobile services in their product portfolios. Banks, on the one hand, need to take cognizance of the needs and wishes of some of their most attractive customer groups. On the other hand, the advantages that MFS potentially bring to a bank are too palpable to deny. In order to assess the implications of the survey results, it would be useful to have a look at the outset of the banking sector.

\subsection{Outset of the Banking Environment}

Bank products are of immaterial nature, which can be sold with the help of computer networks spanning across the globe [16]. The ongoing globalization and technological developments, particularly the Internet have made it possible for banks to offer their services in far-flung areas without investing money to build branches and hire additional staff. This opportunity is a two-way street: On the one hand, a bank gets access to new markets. On the other hand it is faced with increased competition on its home turf.

To master this combination of opportunities and challenges banks need - apart from business consolidation and cooperation - organic growth. It is, therefore, necessary to retain the existing customer base while simultaneously trying to acquire new, economically prosperous customers. Seen in con-junction with the price-sensitivity of customers and the low relevance of the brand-name, banks are compelled to introduce innovative services that potentially attract prospective customers while retaining others. Even though the brand-name remains a critical factor on account of the need for trust in banking business, the globalization and the technological development, however, have reduced entry barriers so that the number of available, reputed brands has increased significantly; thereby intensifying the competition. 


\subsection{Importance of Mobile Offers}

In the following we briefly discuss some possible effects of Mobile Banking services:

Possible advantages of mobile offers: Apart from fulfilling customer needs and wishes there are a range of concrete advantages that banks might reasonably expect by offering mobile services, for instance increasing sales volume. Catering to specific needs of particular customer groups can help generate not only customer goodwill and image but also revenues.

Possible disadvantages of ignoring mobile offers: In no way of lesser significance are the disadvantages that a missing offer on MFS could potentially cause. Apart from opportunity costs in terms of lost revenues and fees there are customers who are willing to change their bank if it neither offers nor plans to offer mobile services.

Surprisingly $15 \%$ of all survey participants in our customer survey in Germany reiterated this position. Certain groups were even more defiant, with as many as one third participants claiming readiness to change their bank, if it failed to provide mobile services. That this answer is not a mere rhetoric exercise is amplified by the example of First Direct of England, whose every eighth new customer (12\%) stated to have switched to them owing to their service of free SMS alerts [9]. In a recent survey by Forrester Research 25\% of surveyed bank customers in England showed readiness to switch their bank if provided with free MFS elsewhere [4].

The above discussion shows that Mobile Banking offers could become indispensable for banks in a not-so-distant future. The question is now no more of "whether" but of "when". The issue seems to be of "what, how and whom", i.e. what services (scope) should be offered how (mediums) and to whom (target groups). Apart from the fact that the scope of the offered services should be selected carefully to suit one's own customers, following two factors ought to be kept in mind:

i) Need for a clear business focus: MFS should be seen as proper business services with clearly-focused business objectives. One of the past mistakes, it seems, was that the technological solutions were given central focus. The impression gained during bank interviews was that Mobile Banking in its first phase was driven by enthusiastic IT divisions which wanted to make use of the newest technologies available. Ideally it should be business - and not IT - divisions, which decide on the product portfolio based on plausible market studies. While IT divisions undoubtedly play a key role in the implementation of the mobile strategy and should be involved in the conception and management of MFS, e.g. within the 
framework of an interdisciplinary team, the primary area of their work remains within the realm of technological implementation.

ii) Concentration on right customer groups: A related issue is that of concentration on "right” customer groups. Another past mistake, it seems, was that banks - or rather their IT divisions - put high emphasis on groups that can be termed as “technology-fans”. Members of this group are however known to have very heterogeneous financial backgrounds and can not be considered per se attractive for banks. The technological affinity of a customer, though a necessary prerequisite for using Mobile Banking, is not sufficient unto itself to make him a target customer for it. This risk seems to be still present to a certain extent. $75 \%$ of the surveyed banks reported that technologically well-versed sections of the society were treated as top target group for Mobile Banking. In contrast only little over 20\% reported targeting white-collar salaried class. The disparity in the supply and demand can be gauged by the fact that as many as $40 \%$ of all existing users of Mobile Banking amongst our survey participants had belonged to this group. The increased need for the mobility has affected working professionals (salaried class, management and self-employed) the most and they seem to be - as the customer survey revealed and as many telephone interview partners and other experts confirmed - most interesting target groups for Mobile Banking: They are financially well-settled, often on the move and technologically well-versed.

Summarizing, we can say that a stage seems to have been reached where it is prudent to include MFS offers in product portfolios. The exact scope of the services to be offered and prices to be charged should be decided keeping in mind the bank-specific customer structures.

\section{Conclusions \& Outlook}

Previous chapters have shown that Mobile Banking has gained non-negligible relevance. It presents an opportunity for banks to retain their existing, technology-savvy customer base by offering value-added, innovative services and might even help in attracting new customers.

As far as the outlook of Mobile Banking is concerned, the actual scope of offered services will most probably vary from bank to bank, depending on the individual customer structure. In the field of price policy an intelligent mix of free-of-charge and paid-for services is to be recommended in order to induce demand. The main contribution of Mobile Banking, however, can be expected to take place in the strategic field. Mobile Banking is set to become an instrument of differentiation. 
Since many banks realize this threat and are taking preventive measures by introducing MFS offers, Mobile Banking would be generally employed to thwart negative differentiation vis-à-vis rivals. Owing to this, we may expect to see Mobile Banking go into the footsteps of Online Banking, i.e. to become a standard service offered by every bank worth its name. 


\section{References}

[1] Accenture (2001), Through the Wireless Window: Where Do We Grow From Here?, 2001, available at: http://accenture.com/xdoc/en/industries/products/cgs/mcommercewhitepaper.pdf, as on 18.05.2005.

[2] Anckar, B. and D. D’Incau, (2002), Value-Added Services in Mobile Commerce: An Analytical Framework and Empirical Findings from a National Consumer Survey, 2002, available at: http://csdl.computer.org/comp/proceedings/hicss/2002/1435/03/14350086b.pdf, as on 10.12.2004.

[3] Buse, S. (2002), "Der mobile Erfolg - Ergebnisse einer empirischen Untersuchung in ausgewählten Branchen”, in: Keuper, F. (Eds.): Electronic Business und Mobile Business - Ansätze, Konzepte und Geschäftsmodelle, Gabler Verlag, Wiesbaden, 2002, pp. 91-116.

[4] eMarketer (2006), UK Online Banking: Not Mobile Yet, 18.01.2006, available at: http://www.emarketer.com/Articles/Print.aspx?1003780, as on 09.02.2006.

[5] Financial Times Deutschland (2005), Deutscher Mobilfunkmarkt legt 2004 kräftig zu, 11.01.2005, available at: http://www.ftd.de/tm/it/1105375717003.html, as on 19.01.2005.

[6] Fundamo (Pty) Ltd. (2005), M-Banking in Africa - showing signs of growth, July 2005, available at: http://www.fundamo.com/index.asp?pgid=30, as on 09.02.2006.

[7] Georgi, F. and J. Pinkl (2005), "Mobile Banking in Deutschland - der zweite Anlauf”, Die Bank, Bank-Verlag, Berlin, Issue 3/2005, pp. 57-61.

[8] Hindu, The (2006), UCO Bank launches 'anywhere branch banking', 07.02.2006, available at: http://www.hindu.com/2006/02/07/stories/2006020706480500.htm, as on 14.02.2006.

[9] Karsch, W. (2004), "Mobile Banking: Vor dem Durchbruch in Deutschland”, Die Bank, Bank-Verlag, Berlin, Issue 9/2004, pp. 70-72.

[10] Kemper, H.-G. and E. Wolf (2005), "Iterative Process Models for Mobile Application Systems: A Framework”, Proceedings of the 23rd International Conference on Information System, pp. 401-413, available at: http://www.bwi.unistuttgart.de, as on: 10.12.2004. 
[11] Köhler, V. (2004), “Integrierter Multikanalvertrieb als Antwort auf den Strukturwandel”, in: Effert, D. and V. Köhler (Eds.): Wettbewerb der Vertriebssysteme, Gabler Verlag, Wiesbaden, 2004, pp. 19-39.

[12] Kolbow, B. (2005), Trend geht zum Mobile Banking, 28.07.2005, available at: http://www.n24.de/index.php?n2005072816191600002, as on 19.08.2005.

[13] Korea Times, The (2006), Mobile Banking More Than Doubles, 01.02.2006, available at: http://times.hankooki.com/lpage/biz/200602/kt2006020122165711910.htm, as on 10.02.2006.

[14] Luber, A. (2004), Kundennutzen und Vertriebsimplikationen mobiler Vertriebstechnologien im Wertpapiergeschäft, Deutscher Universitätsverlag, Wiesbaden, 2004.

[15] Müller-Veerse, F. (2000), Mobile Commerce Report, 2000, available at: http://www.dad.be/library/pdf/durlacher1.pdf, as on 18.05.2005.

[16] Mustafa N., A. Oberweis and T. Schnurr (2002), "Mobile Banking und Sicherheit im Mobile Commerce”, in: Silberer, G., J. Wohlfahrt and T. Wilhelm (Eds.): Mobile Commerce - Grundlagen, Geschäftsmodelle, Erfolgsfaktoren, Gabler Verlag, Wiesbaden, 2002, pp. 353-372.

[17] Postbank (2004), Postbank and T-Mobile Deutschland agree a strategic cooperation in the area of mobile Financial Services, Press release, 11.03.2004, available at: http://www.postbank.de/pbde_ag_home/pbde_pr_presse.html, as on 28.10.2004.

[18] Research Project Mobile Commerce (2006), Mobile Banking Stages a Remarkable Come-back in Germany, Press release, University of Hamburg, 19.01.2006, available at: http://www1.uni-hamburg.de/mcommerce/banking/press/PR20060119.prf, as on 09.02.2006.

[19] Société Générale (2005), Société Générale Group - 2004 Annual Report, available at: http://www.socgen.com/sg/file/fichierig/documentIG_5197/ra-2004-va.pdf, as on 18.10.2005.

[20] Süddeutsche Zeitung (2006), Preisverfall bei Mobilfunk - Die Underdogs liebäugeln mit Schulterschluss, 14.02.2006, available at: http://www.sueddeutsche.de/wirtschaft/artikel/180/70110/, as on 14.02.2006.

[21] Tiwari, R. and S. Buse (2006), The Mobile Commerce Prospects: A Strategic Analysis of Opportunities in the German Banking Sector, unpublished, Hamburg, 2006. 
[22] Tae-Gyu, Kim (2006), "Korea Leads World in Mobile Banking”, The Korea Times, 31.01.2006, available at:

http://times.hankooki.com/lpage/biz/200601/kt2006013013175911860.htm, as on 10.02.2006.

[23] TMCnet Communications (2006), China Bank posts P3.04-B income in '05, 13.02.2006, available at: http://www.tmcnet.com/usubmit/2006/02/13/1368613.htm, as on 10.02.2006. 